\title{
The Evaluation and Light, Abrasion Fastness Values of Colours Obtained from Some Dyeing Plants in Silk Yarn
}

\author{
Kayabaşı Nuran ${ }^{1}$, Şanlı H. Sinem², Söylemezoğlu Feryal ${ }^{1}$ \\ ${ }^{1}$ School of Home Economics, Ankara University, Ankara, Turkey \\ ${ }^{2}$ Art and Design Faculty, Gazi University, Ankara, Turkey \\ Email address: \\ kayabasinuran@gmail.com (K. Nuran), hurrem@gazi.edu.tr (Ş. H. Sinem), fersoy@ankara.edu.tr (S. Feryal)
}

To cite this article:

Kayabaşı Nuran, Şanlı H. Sinem, Söylemezoğlu Feryal. The Evaluation and Light, Abrasion Fastness Values of Colours Obtained from Some Dyeing Plants in Silk Yarn. American Journal of Applied Chemistry. Vol. 3, No. 2, 2015, pp. 48-56. doi: 10.11648/j.ajac.20150302.13

\begin{abstract}
The silk yarn produced in Turkey finds also an area of usage in the textile handicraft carpet with some areas of textile. As the textile handicraft silk carpets painted with vegetable dyes are very valuable, they are prefered by consumers in the inner and outer markets. In this research; the silk yarn was painted with sage (Salvia sp.), safflower (Carthamus tinctorius L.), walnut (Juglans regia L.), madder (Rubia tinctorium L.) and camomile (Anthemis tinctoria L.) plants. During the painting, the mordant and non-mordant method has been used. $100 \%$ plant, and 3\% mordant (sodium chloride, ferrosulphate, coppersulphate, alum of aluminium and potassium bichromate) was used during the painting. The mordant process was made with the pre-mordant method by using 3\% mordant with a single mordant and adding two mordants in an equal ratio $(1.5 \%+1.5 \%) .80$ painting was made totally and different colours and tones depending on the plants feature was acquired. The acquired colours were examined light and abrasion fastnesses. The acquired colours were evaluated objectively and subjectively.
\end{abstract}

Keywords: Vegetable Dyeing, Silk Yarn, Sage, Safflower, Walnut, Madder, Camomile, Light Fastness, Abrasion Fastness, Objective Evaluation, Subjective Evaluation

\section{Introduction}

The silk yarn produced in Turkey finds also an area of usage in the textile handicraft carpet with some areas of textile. As the textile handicraft silk carpets painted with vegetable dyes are very valuable, they are prefered by consumers in the inner and outer markets. Although silk production in our country decreased in recent years, production is still continuing in some regions within the framework of handicrafts. Silks are used in carpets, rugs and hand weaving.

In this research; the silk yarn was painted with sage (Salvia sp.), safflower (Carthamus tinctorius L.), walnut (Juglans regia L.), madder (Rubia tinctorium L.) and camomile (Anthemis tinctoria L.) plants. During the painting, the mordant and non-mordant method has been used. $100 \%$ plant, and 3\% mordant (sodium chloride, ferrosulphate, coppersulphate, alum of aluminium and potassium bichromate) was used during the painting. The mordant process was made with the pre-mordant method by using $3 \%$ mordant with a single mordant and adding two mordants in an equal ratio $(1.5 \%+1.5 \%) .80$ painting was made totally and different colours and tones depending on the plants feature was acquired. The acquired colours were examined light and abrasion fastnesses. The acquired colours were evaluated objectively and subjectively.

\section{Material and Methods}

\subsection{Material}

The materials of the experiment consists of sage (Salvia sp), safflower (Carthamus tinctorius L.), walnut (Juglans regia L.), madder (Rubia tinctorium L.) and camomile (Anthemis tinctoria L.) plants, silk carpet yarns, sodium chloride, ferrosulphate, coppersulphate, alum of aluminium and potassium bichromate mordants.

\subsection{Methods}

For dyeing of silk yarns with sage, safflower, walnut, madder and camomile determined in material, mordanting and without mordanting methods were applied. 


\subsubsection{Preparation of Dye Extract}

To obtain the penetration of dye matter to water, dried whole plants were broken up into small pieces. Whole plants were taken in accordence with silk weight at the rate of the $100 \%$. Pure water was used in accordence with silk weight at the rate of the $1 / 50$. And then plant pieces were boiled in this water for one hour. At the end of time plants remnants were filtered and putted away from the water. In this way dye extract was obtained.

\subsubsection{Dyeing without Mordant}

Previously damped silk yarns were boiled in dye extract for one hour. During the boiling decreased water is added equal to vaporized amount. Then it was cooled, rinsed with cold water and dried at shading and airy place.

\subsubsection{Dyeing with Mordant}

Firstly, silk carpet yarns that will be dyed will be mordanted. For this action, in conformity with the weight of silk yarns that will be dyed, 3\% the sodium chloride, ferrosulphate, coppersulphate, alum of aluminium and potassium bichromate were taken and they were dissolved in water. The mordant process was made with the pre-mordant method by using 3\% mordant with a single mordant and adding two mordants in an equal ratio $(1.5 \%+1.5 \%)$. Then, silk yarns that will be mordanted was put in water and boiled during one hour. After one hour, silk yarns were ready for dyeing by wringing. Mordanted silk yarns were boiled in the previously prepared dye extract for one hour. Then, it was cooled, rinsed with cold water and dried at shading and airy place (Şanlı et all. 2011).

\subsubsection{Light Fastness Determination}

Light fastness determination was done according to TS 867 prepared by TSE (For Dyed or Pressed Textiles Colour Fastness Testing Methods- Colour Fastness Determination Methods Facing Sunlight) (Anonymous 1984 a) and DIN 5033 (Farbmessung Begriffe der Fabrmetrik) (Anonymous 1970).

For light fastness determination, (scale is bands by using different blue dyes that are leveled 1 to 8) blue wool scale was used with silk yarn samples. Blue scale was pasted on cardboard, its length is $1 \mathrm{~cm}$., and width is $6 \mathrm{~cm}$. They were pasted 1 to 8 in turns. Dyed silk yarn samples were wrapped parallels each other on cardboard with $1 \mathrm{~cm}$. length and $6 \mathrm{~cm}$. width. Bands were cut in $7 \mathrm{~cm}$. and $3 \mathrm{~cm}$. width and were put on each other and a volume was made. With silk yarn samples prepared as two parallels that were put on the cardboard before, blue wool scale were put on this volume. Silk yarn samples and half of the blue wool scale was closed as well as the other half of the scale were kept on the exposure of the sun light. This scale was put before the sun light in angle of $45^{\circ}$ and was controlled each day. In conformity with fading, silk yarn samples were evaluated.

\subsubsection{Abrasion Fastness Determination}

Abrasion fastness determination was done according to TS 717 prepared by TSE (For Dyed or Pressed Textiles Colour
Fastness Testing Methods- Determination of Colour Fastness to Abrasion) (Anonymous 1978) and TS 423 (Using Methods of the Gray Scale for Sum up the Staining "leaking of dye" and DisColouring "Chancing of Colour" in the Determination of Colour Fastness of Textiles) (Anonymous 1984 b).

Dyed silk yarns were wrapped on each cardboard material in $14 \mathrm{~cm}$.X $5 \mathrm{~cm}$., in parallels and side-by-side. Cotton tissue with bezayağ 1 that was cut in $5 \mathrm{~cm}$.X $5 \mathrm{~cm}$. and that was dry and without dye was put at the point of experiment device, dry samples which were prepared two parallels under the weightiness of 900 gram, were made rub on a floor line in proportion of their $10 \mathrm{~cm}$. part during 10 second in 10 times. Colour flow in to cotton tissue without dry was evaluated in conformity with gray scale and TS 423 .

\subsubsection{Evaluation of Obtained Colour with Subjective Method}

Naming obtained colours was arranged subjectively. Obtained colours with these methods were named by the commission consisted of specialists of Ankara University Home Economics.

For the naming, dyed silk yarn samples were spreat on a white ground where the sunlight comes from the side and they formed into groups according to their colours and tone differences. And also Harmancıoğlu (1955) was considered for the naming of the colours.

\subsubsection{Evaluation of Obtained Colour with Objective Method}

In objective evaluation, firstly L (coordinate of brightness), a (red-green coordinate) and b (blue-yellow coordinate) values were measured and then $\mathrm{dE}$ (value of colour difference) was calculated by using Sodexim 1866 Tristimilus Colourimeter. While making colour measurement with colourimeter, silk carpet yarns without dye were accepted as reference value and colours obtained in dyeings were calculated according to the reference value. By calculating $\mathrm{L}$, $a$ and $b$ values as $L-L_{x}, a-a_{x}$ and $b-b_{x}$, their square root value of total squares was determined as dE. Results of calculations show that if $\mathrm{dE}$ value is low, difference is low, if $\mathrm{dE}$ value is high difference is also high (Anonymous 2000, Arlı et all. 2003, Kayabaş1 et all. 2003). Values and their meaning used for calculation of $\mathrm{dE}$ values are given below:

L: brightness coordinate of white silk (without dye),

$\mathrm{L}_{\mathrm{x}}$ : brightness coordinate of each dyed yarn,

L max: 100 white

L min: 10 black

a: red- green coordinate of white silk yarns

$a_{x}$ : red- green coordinate of each dyed yarn

+392 : dark red

-392: dark green

b: blue- yellow coordinate of white silk yarns

$b_{\mathrm{x}}$ : blue- yellow coordinate of each dyed yarn

+157: dark yellow

-157: dark blue 


$$
d E: \sqrt{(L-L X)^{2}+(a-a X)^{2}+(b-b X)^{2}}
$$

\section{Results and Discussion}

Sage, safflower, walnut, madder and camomile were taken in proportion of $100 \%$ according to the weight of silk yarns that will be dyed, then mordanting dyeing were realized by using the sodium chloride, ferrosulphate, coppersulphate, alum of aluminium and potassium bichromate mordants.
The mordant process was made with the pre-mordant method by using $3 \%$ mordant with a single mordant and adding two mordants in an equal ratio $(1.5 \%+1.5 \%)$. Totally 80 dyeing were obtained, 75 are with mordant, and 5 are without mordant. Colours obtained as result of dyeing were fixed and given in Table 1,2 in objective and subjective methods. Colours obtained as result of dyeing were given in Table 3 in light and abrasion fastness methods.

Table 1. Evaluation of colours obtained from plants with objective method in silk yarns

\begin{tabular}{|c|c|c|c|c|c|c|}
\hline Plants & Mordants & Mordant ratio (\%) & $\mathbf{L x}$ & $\mathbf{a x}$ & bx & dE \\
\hline \multirow{16}{*}{ Sage (Salvia sp) } & Alum of aluminium & & 52.56 & -5.51 & 33.71 & 23.04 \\
\hline & Ferrosulphate & & 36.91 & 3.22 & 16.90 & 35.24 \\
\hline & Coppersulphate & 3 & 48.79 & -0.003 & 35.59 & 29.39 \\
\hline & Potassium-bichromate & & 56.72 & -0.89 & 40.92 & 29.01 \\
\hline & Sodium chloride & & 57.55 & -2.69 & 25.38 & 18.00 \\
\hline & Alum of aluminium + Ferrosulphate & \multirow{11}{*}{$1.5+1.5$} & 41.06 & 0.63 & 22.25 & 30.51 \\
\hline & Alum of aluminium + Coppersulphate & & 49.42 & 4.29 & 38.47 & 33.42 \\
\hline & Alum of aluminium + Potassium-bichromate & & 47.37 & 0.45 & 40.90 & 33.70 \\
\hline & Alum of aluminium+ Sodium chloride & & 54.39 & -10.40 & 39.08 & 24.15 \\
\hline & Ferrosulphate + Coppersulphate & & 44.58 & -1.2 & 28.12 & 28.01 \\
\hline & Ferrosulphate + Potassium-bichromate & & 53 & 0.51 & 35.42 & 27.47 \\
\hline & Ferrosulphate + Sodium chloride & & 58.19 & 2.91 & 26.94 & 23.12 \\
\hline & Coppersulphate + Potassium-bichromate & & 41.15 & 2.82 & 24.24 & 32.07 \\
\hline & Coppersulphate + Sodium chloride & & 52.38 & -2.21 & 38.67 & 28.26 \\
\hline & Potassiumbichromate+ Sodium chloride & & 58.44 & 3.16 & 34.74 & 27.01 \\
\hline & Without mordant & & 63.03 & 3.37 & 23.37 & 21.49 \\
\hline \multirow{16}{*}{$\begin{array}{l}\text { Safflower (Carthamus } \\
\text { tinctorius L.) }\end{array}$} & Alum of aluminium & \multirow{5}{*}{3} & 54 & -8.94 & 45.44 & 30.23 \\
\hline & Ferrosulphate & & 42.4 & -2.32 & 27.25 & 28.80 \\
\hline & Coppersulphate & & 58.59 & -1.21 & 38.57 & 26.52 \\
\hline & Potassium-bichromate & & 62.32 & 2.41 & 45.28 & 33.30 \\
\hline & Sodium chloride & & 55.63 & -0.65 & 32.26 & 23.68 \\
\hline & Alum of aluminium + Ferrosulphate & \multirow{11}{*}{$1.5+1.5$} & 40.84 & 0.81 & 29.88 & 32.55 \\
\hline & Alum of aluminium + Coppersulphate & & 52.93 & -0.45 & 37.49 & 28.21 \\
\hline & Alum of aluminium + Potassium-bichromate & & 52.003 & -2.09 & 41.99 & 30.91 \\
\hline & Alum of aluminium + Sodium chloride & & 51.98 & 0.92 & 38.65 & 30.23 \\
\hline & Ferrosulphate + Coppersulphate & & 43.31 & 3.25 & 25.8 & 31.08 \\
\hline & Ferrosulphate+ Potassium-bichromate & & 47.48 & 4.47 & 38.68 & 34.62 \\
\hline & Ferrosulphate + Sodium chloride & & 38.25 & -3.67 & 29.95 & 32.42 \\
\hline & Coppersulphate + Potassium-bichromate & & 48.74 & 4.39 & 34.72 & 31.78 \\
\hline & Coppersulphate+ Sodium chloride & & 53.67 & 1.53 & 35.13 & 27.69 \\
\hline & Potassiumbichromate + Sodium chloride & & 52.45 & -2.24 & 40.60 & 29.60 \\
\hline & Without mordant & & 67.73 & -4.14 & 44.27 & 28.89 \\
\hline \multirow{10}{*}{ Walnut (Juglans regia L.) } & Alum of aluminium & & 21.67 & 5.15 & 5.71 & 50.91 \\
\hline & Ferrosulphate & & 21.2 & 2.07 & 5.21 & 50.16 \\
\hline & Coppersulphate & 3 & 21.85 & 7.02 & 7.45 & 51.20 \\
\hline & Potassium-bichromate & & 21.19 & 3.43 & 9.11 & 49.82 \\
\hline & Sodium chloride & & 22.24 & 4.28 & 10.47 & 49.01 \\
\hline & Alum of aluminium + Ferrosulphate & \multirow{5}{*}{$1.5+1.5$} & 20.01 & 4.25 & 4.6 & 52.25 \\
\hline & Alum of aluminium + Coppersulphate & & 25.11 & 5.27 & 7.98 & 47.48 \\
\hline & Alum of aluminium+ Potassium-bichromate & & 20.03 & 4.95 & 5.51 & 52.29 \\
\hline & Alum of aluminium + Sodium chloride & & 21.64 & 1.42 & 7.81 & 48.88 \\
\hline & Ferrosulphate + Coppersulphate & & 23.27 & -0.20 & 6.44 & 47.14 \\
\hline
\end{tabular}




\begin{tabular}{|c|c|c|c|c|c|c|}
\hline Plants & Mordants & Mordant ratio (\%) & $\mathbf{L x}$ & $\mathbf{a x}$ & bx & dE \\
\hline & Ferrosulphate + Potassium-bichromate & & 17.88 & 4.003 & 6.25 & 53.60 \\
\hline & Ferrosulphate + Sodium chloride & & 26.30 & 6.31 & 11.13 & 46.37 \\
\hline & Coppersulphate+ Potassium-bichromate & & 25.56 & 4.72 & 8.30 & 46.76 \\
\hline & Coppersulphate + Sodium chloride & & 15.30 & -0.11 & 5.87 & 54.53 \\
\hline & Potassiumbichromate + Sodium chloride & & 23.54 & 5.19 & 7.60 & 48.87 \\
\hline & Without mordant & & 21.006 & 4.76 & 6.45 & 51.13 \\
\hline \multirow{16}{*}{$\begin{array}{l}\text { Madder (Rubia } \\
\text { tinctorium L.) }\end{array}$} & Alum of aluminium & \multirow{5}{*}{3} & 39.19 & 28.93 & 24.82 & 53.64 \\
\hline & Ferrosulphate & & 24.08 & 6.03 & 11.57 & 48.05 \\
\hline & Coppersulphate & & 43.24 & 17.65 & 15.05 & 41.69 \\
\hline & Potassium-bichromate & & 30.60 & 17.96 & 11.28 & 50.21 \\
\hline & Sodium chloride & & 33.32 & 9.44 & 15.38 & 41.99 \\
\hline & Alum of aluminium + Ferrosulphate & \multirow{11}{*}{$1.5+1.5$} & 32.04 & 15.35 & 12.46 & 47.21 \\
\hline & Alum of aluminium + Coppersulphate & & 49.32 & 16.06 & 20.09 & 37.21 \\
\hline & Alum of aluminium + Potassium-bichromate & & 41.25 & 28.60 & 40.39 & 56.34 \\
\hline & Alum of aluminium + Sodium chloride & & 38.43 & 30.38 & 21.38 & 54.99 \\
\hline & Ferrosulphate + Coppersulphate & & 40.66 & 11.66 & 16.25 & 38.29 \\
\hline & Ferrosulphate + Potassium-bichromate & & 31.58 & 18.08 & 14.39 & 49.25 \\
\hline & Ferrosulphate + Sodium chloride & & 35.76 & 18.85 & 14.71 & 47.05 \\
\hline & Coppersulphate+ Potassium-bichromate & & 49.15 & 15.30 & 16.03 & 36.68 \\
\hline & Coppersulphate + Sodium chloride & & 42.92 & 10.13 & 12.21 & 35.69 \\
\hline & Potassiumbichromate+ Sodium chloride & & 30.96 & 25.94 & 15.71 & 55.49 \\
\hline & Without mordant & & 35.05 & 23.08 & 21.29 & 50.71 \\
\hline \multirow{16}{*}{$\begin{array}{l}\text { Camomile } \\
\text { (Anthemis tinctoria L.) }\end{array}$} & Alum of aluminium & & 53.4 & 3.92 & 35.10 & 29.47 \\
\hline & Ferrosulphate & & 43.86 & -23.91 & 25.75 & 23.49 \\
\hline & Coppersulphate & 3 & 50.17 & 3.69 & 30.22 & 28.47 \\
\hline & Potassium-bichromate & & 49.75 & 10.88 & 33.55 & 35.60 \\
\hline & Sodium chloride & & 58.12 & -4.07 & 21.85 & 15.56 \\
\hline & Alum of aluminium + Ferrosulphate & \multirow{11}{*}{$1.5+1.5$} & 46.60 & 1.80 & 28.42 & 28.59 \\
\hline & Alum of aluminium + Coppersulphate & & 48.54 & -1.47 & 35.55 & 28.66 \\
\hline & Alum of aluminium + Potassium-bichromate & & 53.18 & 5.53 & 41.10 & 34.31 \\
\hline & Alum of aluminium + Sodium chloride & & 53.86 & 8.60 & 36.10 & 33.37 \\
\hline & Ferrosulphate + Coppersulphate & & 37.36 & 1.62 & 19.60 & 33.91 \\
\hline & Ferrosulphate + Potassium-bichromate & & 45.95 & 6.05 & 32.96 & 33.65 \\
\hline & Ferrosulphate + Sodium chloride & & 48.17 & 3.87 & 69.08 & 57.30 \\
\hline & Coppersulphate+ Potassium-bichromate & & 46.45 & 3.69 & 34.65 & 32.54 \\
\hline & Coppersulphate + Sodium chloride & & 52.88 & 4.4 & 27.32 & 26.62 \\
\hline & Potassiumbichromate + Sodium chloride & & 56.86 & 2.45 & 35.75 & 27.54 \\
\hline & Without mordant & & 58.53 & -14.79 & 31.44 & 14.65 \\
\hline
\end{tabular}

According to the Table 1, it is shown that the colours obtained from sage plants measured with colorimeter, $\mathrm{dE}$ value (colour difference) changes between 18.00 and 35.24 . The highest value, 35.24 , was obtained by using $3 \%$ ferrosulphate mordant in practice, the lowest value, 18.00 , was obtained by using 3\% sodium-chloride mordant in practice.

Colors obtained from safflower plants measured with colorimeter, $\mathrm{dE}$ value (colour difference) changes between 23.68 and 34.62. The highest value, 34.62, was obtained by using ferrosulphate+ potassium-bicromate mordants in practice, the lowest value, 23.68 , was obtained by using $3 \%$ sodium-chloride mordant in practice. These results have supported by Kayabaş1 et all. 2012.

It is shown that the colours obtained from walnut plants measured with colorimeter, $\mathrm{dE}$ value (colour difference) changes between 46.37 and 54.53. The highest value, 54.53, was obtained by using coppersulphate + sodium-chloride mordants in practice, the lowest value, 46.37 , was obtained by using ferrosulphate + sodium-chloride mordants in practice.

Colors obtained from madder plants measured with colorimeter, $\mathrm{dE}$ value (colour difference) changes between 35.69 and 56.34. The highest value, 56.34, was obtained by using alum of aluminium + potassium-bicromate mordants in practice, the lowest value, 35.69, was obtained by using coppersulphate+sodium-chloride mordants in practice.

It is shown that the colours obtained from camomile plants measured with colorimeter, $\mathrm{dE}$ value (colour difference) changes between 14.65 and 57.30. The highest value, 57.30, was obtained by using ferrosulphate + sodium-chloride 
mordants in practice, the lowest value, 14.65, was obtained by using without mordant in practice.
The colours obtained from plants with subjective method in this experiment are fixed and given in Table 2.

Table 2. The colours obtained from plants with subjective method in silk yarns

\begin{tabular}{|c|c|c|c|}
\hline Plants & Mordants & Mordant ratio (\%) & Obtained from colours \\
\hline \multirow[b]{2}{*}{ Sage (Salvia sp.) } & $\begin{array}{l}\text { Alum of aluminium } \\
\text { Ferrosulphate } \\
\text { Coppersulphate } \\
\text { Potassium-bichromate } \\
\text { Sodium chloride }\end{array}$ & 3 & $\begin{array}{l}\text { Wet straw } \\
\text { Brownish green } \\
\text { Light virgin olive oil } \\
\text { Sulphur colour } \\
\text { Greenish cream }\end{array}$ \\
\hline & $\begin{array}{l}\text { Alum of aluminium }+ \text { Ferrosulphate } \\
\text { Alum of aluminium }+ \text { Coppersulphate } \\
\text { Alum of aluminium }+ \text { Potassium-bichromate } \\
\text { Alum of aluminium+ Sodium chloride } \\
\text { Ferrosulphate+ Coppersulphate } \\
\text { Ferrosulphate+ Potassium-bichromate } \\
\text { Ferrosulphate+ Sodium chloride } \\
\text { Coppersulphate+ Potassium-bichromate } \\
\text { Coppersulphate+ Sodium chloride } \\
\text { Potassiumbichromate+ Sodium chloride } \\
\text { Without mordant }\end{array}$ & $1.5+1.5$ & $\begin{array}{l}\text { Light khaki } \\
\text { Light virgin olive oil } \\
\text { Light sulphur colour } \\
\text { Straw } \\
\text { Green } \\
\text { Dark honey } \\
\text { Dark cream } \\
\text { Green } \\
\text { Light virgin olive oil } \\
\text { Greenish yellow } \\
\text { Greenish cream }\end{array}$ \\
\hline \multirow[b]{2}{*}{$\begin{array}{l}\text { Safflower (Carthamus } \\
\text { tinctorius L.) }\end{array}$} & $\begin{array}{l}\text { Alum of aluminium } \\
\text { Ferrosulphate } \\
\text { Coppersulphate } \\
\text { Potassium-bichromate } \\
\text { Sodium chloride } \\
\end{array}$ & 3 & $\begin{array}{l}\text { Honey colour } \\
\text { Virgin olive oil } \\
\text { Naphtha } \\
\text { Honey colour } \\
\text { Chick yolk }\end{array}$ \\
\hline & $\begin{array}{l}\text { Alum of aluminium+ Ferrosulphate } \\
\text { Alum of aluminium+ Coppersulphate } \\
\text { Alum of aluminium+ Potassium-bichromate } \\
\text { Alum of aluminium+ Sodium chloride } \\
\text { Ferrosulphate+ Coppersulphate } \\
\text { Ferrosulphate+ Potassium-bichromate } \\
\text { Ferrosulphate+ Sodium chloride } \\
\text { Coppersulphate+ Potassium-bichromate } \\
\text { Coppersulphate+ Sodium chloride } \\
\text { Potassiumbichromate+ Sodium chloride } \\
\text { Without mordant }\end{array}$ & $1.5+1.5$ & $\begin{array}{l}\text { Light henna } \\
\text { Naphtha } \\
\text { Honey colour } \\
\text { Honey colour } \\
\text { Honey colour } \\
\text { Mustard } \\
\text { Dark Mustard } \\
\text { Dark naphtha } \\
\text { Naphtha } \\
\text { Beige } \\
\text { Chick yolk }\end{array}$ \\
\hline \multirow{3}{*}{ Walnut (Juglans regia L.) } & $\begin{array}{l}\text { Alum of aluminium } \\
\text { Ferrosulphate } \\
\text { Coppersulphate } \\
\text { Potassium-bichromate } \\
\text { Sodium chloride }\end{array}$ & 3 & $\begin{array}{l}\text { Bitter coffee } \\
\text { Bitter coffee } \\
\text { Tree root colour } \\
\text { Bitter coffee } \\
\text { Tree root colour }\end{array}$ \\
\hline & $\begin{array}{l}\text { Alum of aluminium }+ \text { Ferrosulphate } \\
\text { Alum of aluminium }+ \text { Coppersulphate } \\
\text { Alum of aluminium }+ \text { Potassium-bichromate } \\
\text { Alum of aluminium }+ \text { Sodium chloride } \\
\text { Ferrosulphate+ Coppersulphate } \\
\text { Ferrosulphate+ Potassium-bichromate } \\
\text { Ferrosulphate+ Sodium chloride } \\
\text { Coppersulphate+ Potassium-bichromate } \\
\text { Coppersulphate+ Sodium chloride } \\
\text { Potassiumbichromate+ Sodium chloride } \\
\text { Without mordant }\end{array}$ & $1.5+1.5$ & $\begin{array}{l}\text { Bitter coffee } \\
\text { Bitter coffee } \\
\text { Bitter coffee } \\
\text { Bitter coffee } \\
\text { Bitter coffee } \\
\text { Bitter coffee } \\
\text { Bitter coffee } \\
\text { Brown } \\
\text { Tree root colour } \\
\text { Brown } \\
\text { Brown }\end{array}$ \\
\hline & $\begin{array}{l}\text { Alum of aluminium } \\
\text { Ferrosulphate } \\
\text { Coppersulphate } \\
\text { Potassium-bichromate }\end{array}$ & 3 & $\begin{array}{l}\text { Red orange } \\
\text { Milky chocolate } \\
\text { Dark onion peel } \\
\text { Dark rose }\end{array}$ \\
\hline
\end{tabular}




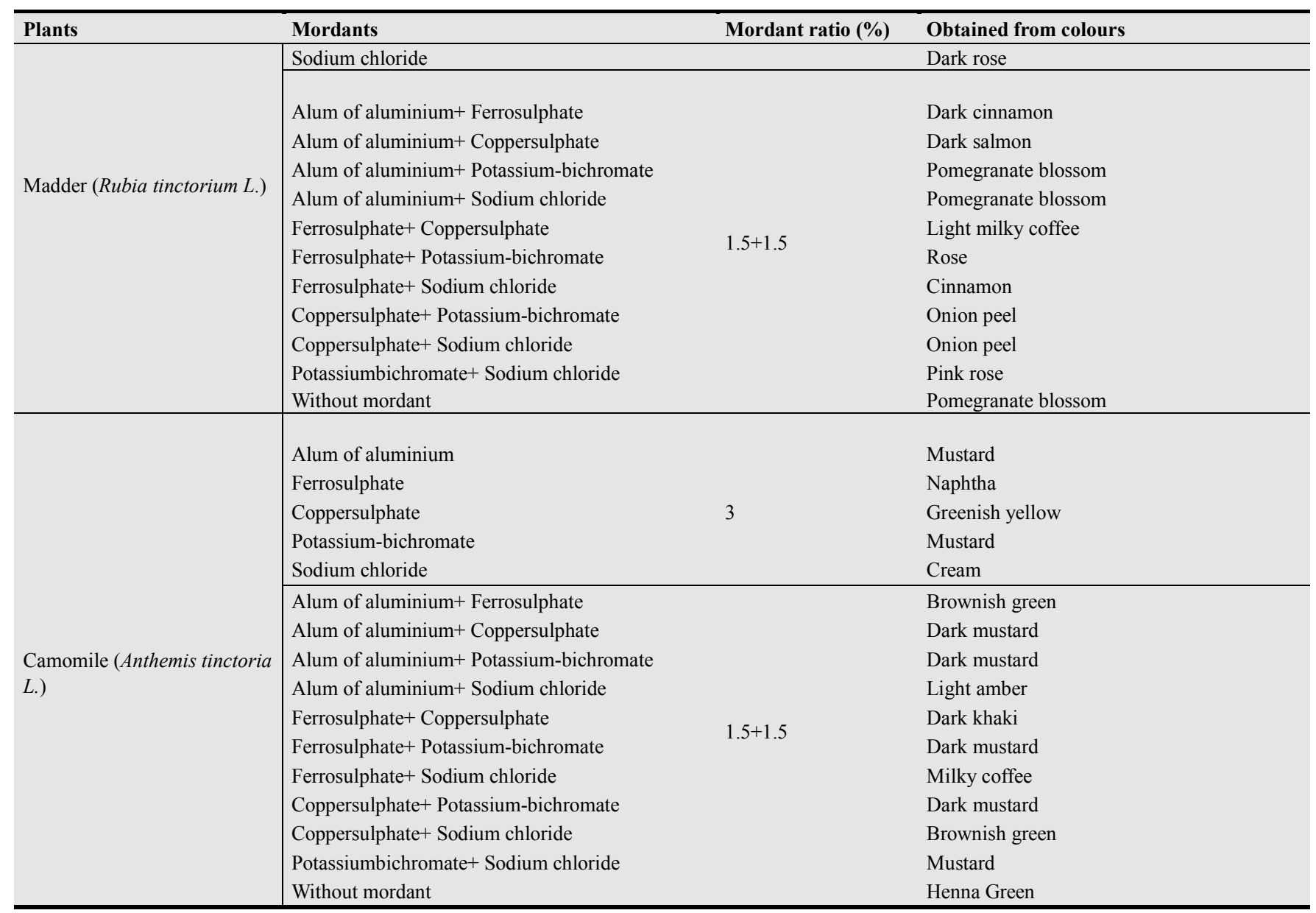

When Table 2 is examined, silk yarns and sage (Salvia sp.) plants $3 \%$ mordant ratio with alum of aluminium wet straw, with ferrosulphate brownish green, with coppersulphate light virgin olive oil, with potassium-bichromate sulphur colour, with sodium-chloride greenish cream colours were obtained. Silk yarns and $1.5+1.5 \%$ mordant ratio with alum of aluminium + ferrosulphate light khaki, with alum of aluminium + coppersulphate and coppersulphate + sodium chloride light virgin olive oil, with alum of aluminium+ potassium-bichromate light sulphur colour, with alum of aluminium + sodium chloride straw, with ferrosulphate+ coppersulphate and coppersulphate + potassium-bichromate green, with ferrosulphate+ potassium-bichromate dark honey, with ferrosulphate + sodium chloride dark cream, with potassiumbichromate + sodium chloride greenish yellow and greenish cream without mordant colours were obtained.

Silk yarns and safflower (Carthamus tinctorius L.) plants 3\% mordant ratio with alum of aluminium and potassiumbichromate honey colour, with ferrosulphate virgin olive oil, with coppersulphate naphtha, with sodium-chloride chick yolk colours were obtained. Silk yarns and $1.5+1.5 \%$ mordant ratio with alum of aluminium + ferrosulphate light henna, with alum of aluminium + coppersulphate and coppersulphate + sodium chloride naphtha, with alum of aluminium + potassium-bichromate, alum of aluminium + sodium chloride and ferrosulphate + coppersulphate honey colour, ferrosulphate + potassium-bichromate mustard, with ferrosulphate + sodium chloride dark mustard, with coppersulphate + potassium-bichromate dark naphtha, with potassiumbichromate + sodium chloride beige and chick yolk without mordant colours were obtained.

Silk yarns and walnut (Juglans regia L.) plants 3\% mordant ratio with alum of aluminium, ferrosulphate and potassium-bichromate bitter coffee, with coppersulphate and sodium-chloride tree root colours were obtained. Silk yarns and $1.5+1.5 \%$ mordant ratio with alum of aluminium+ ferrosulphate, alum of aluminium + coppersulphate, alum of aluminium + potassium-bichromate, alum of aluminium + sodium chloride, ferrosulphate+ coppersulphate, ferrosulphate + potassium-bichromate and ferrosulphate + sodium chloride bitter coffee, with coppersulphate+ potassium-bichromate, potassiumbichromate + sodium chloride and without mordant brown, coppersulphate+ sodium chloride tree root colours were obtained.

Silk yarns and madder (Rubia tinctorium L.) plants 3\% mordant ratio with alum of aluminium red orange, with ferrosulphate milky chocolate, with coppersulphate dark onion peel, with potassium-bichromate and sodium-chloride dark rose colours were obtained. Silk yarns and $1.5+1.5 \%$ mordant ratio with alum of aluminium + ferrosulphate dark cinnamon, with alum of aluminium + coppersulphate dark salmon, with alum of aluminium + potassium-bichromate, alum of aluminium + sodium chloride and without mordant pomegranate blossom, with ferrosulphate + coppersulphate 
light milky coffee, with ferrosulphate + potassium-bichromate rose, with ferrosulphate + sodium chloride cinnamon, with coppersulphate + potassium-bichromate and coppersulphate + sodium chloride onion peel and potassiumbichromate+ sodium chloride pink rose colours were obtained.

Silk yarns and camomile (Anthemis tinctoria L.) plants 3\% mordant ratio with alum of aluminium and potassiumbichromate mustard, with ferrosulphate naphtha, with coppersulphate greenish yellow, with sodium-chloride cream colours were obtained. Silk yarns and $1.5+1.5 \%$ mordant ratio with alum of aluminium+ ferrosulphate and coppersulphate + sodium chloride brownish green, with alum of aluminium + coppersulphate, alum of aluminium + potassium-bichromate, ferrosulphate + potassium-bichromate and coppersulphate+ potassium-bichromate dark mustard, with alum of aluminium + sodium chloride light amber, with ferrosulphate + coppersulphate dark khaki, with ferrosulphate + sodium chloride milky coffee, with potassiumbichromate + sodium chloride mustard and henna green without mordant colours were obtained.

Table 3. Light and abrasion fastnesses value of the colours obtained from plants with in silk yarns

\begin{tabular}{|c|c|c|c|c|}
\hline Plants & Mordants & Mordant ratio (\%) & Light fastness & Abrasion fastness \\
\hline \multirow{13}{*}{ Sage (Salvia sp) } & Alum of aluminium & & 6 & $4 / 5$ \\
\hline & Ferro sulphate & & 8 & 4 \\
\hline & Potassium-bichromate & & 7 & 4 \\
\hline & Sodium- chloride & & 5 & $4 / 5$ \\
\hline & Alum of aluminium + Coppersulphate & \multirow{9}{*}{$1.5+1.5$} & 7 & $4 / 5$ \\
\hline & Alum of aluminium + Potassium-bichromate & & 5 & $4 / 5$ \\
\hline & Alum of aluminium + Sodium- chloride & & 6 & $4 / 5$ \\
\hline & Ferrosulphate + Coppersulphate & & 6 & $4 / 5$ \\
\hline & Ferrosulphate + Potassium-bichromate & & 8 & $4 / 5$ \\
\hline & Ferrosulphate + Sodium- chloride & & 6 & $4 / 5$ \\
\hline & Coppersulphate+ Sodium- chloride & & 5 & 4 \\
\hline & Potassiumbichromate + Sodium- chloride & & 6 & $4 / 5$ \\
\hline & Without mordant & & 6 & 5 \\
\hline \multirow{14}{*}{$\begin{array}{l}\text { Safflower (Carthamus tinctorius } \\
\text { L.) }\end{array}$} & Alum of aluminium & \multirow{5}{*}{3} & 5 & 5 \\
\hline & Ferro sulphate & & 6 & $4 / 5$ \\
\hline & Coppersulphate & & 4 & 4 \\
\hline & Potassium-bichromate & & 4 & 5 \\
\hline & Sodium- chloride & & 4 & $4 / 5$ \\
\hline & Alum of aluminium + Ferro sulphate & \multirow{9}{*}{$1.5+1.5$} & 6 & $4 / 5$ \\
\hline & Alum of aluminium + Coppersulphate & & 6 & $4 / 5$ \\
\hline & Alum of aluminium + Potassium-bichromate & & 5 & $4 / 5$ \\
\hline & Ferrosulphate + Potassium-bichromate & & 5 & $3 / 4$ \\
\hline & Ferrosulphate + Sodium- chloride & & 5 & $4 / 5$ \\
\hline & Coppersulphate+ Potassium-bichromate & & 5 & 4 \\
\hline & Coppersulphate + Sodium- chloride & & 5 & $4 / 5$ \\
\hline & Potassiumbichromate + Sodium- chloride & & 4 & $4 / 5$ \\
\hline & Without mordant & & 4 & $4 / 5$ \\
\hline \multirow{9}{*}{ Walnut (Juglans regia L.) } & Alum of aluminium & \multirow{5}{*}{3} & 8 & 4 \\
\hline & Ferro sulphate & & 8 & $2 / 3$ \\
\hline & Coppersulphate & & 6 & 2 \\
\hline & Potassium-bichromate & & 8 & 4 \\
\hline & Sodium- chloride & & 6 & 4 \\
\hline & Alum of aluminium + Ferro sulphate & \multirow{4}{*}{$1.5+1.5$} & 8 & 4 \\
\hline & Alum of aluminium + Coppersulphate & & 6 & $3 / 4$ \\
\hline & Alum of aluminium + Potassium-bichromate & & 7 & $3 / 4$ \\
\hline & Alum of aluminium + Sodium- chloride & & 8 & $3 / 4$ \\
\hline
\end{tabular}




\begin{tabular}{|c|c|c|c|c|}
\hline Plants & Mordants & Mordant ratio (\%) & Light fastness & Abrasion fastness \\
\hline & Ferrosulphate+ Coppersulphate & & 8 & $3 / 4$ \\
\hline & Ferrosulphate+ Potassium-bichromate & & 7 & 4 \\
\hline & Ferrosulphate + Sodium- chloride & & 8 & $3 / 4$ \\
\hline & Coppersulphate+ Potassium-bichromate & & 7 & 3 \\
\hline & Coppersulphate + Sodium- chloride & & 7 & 4 \\
\hline & Potassiumbichromate + Sodium- chloride & & 7 & 4 \\
\hline & Without mordant & & 7 & $4 / 5$ \\
\hline \multirow{16}{*}{ Madder (Rubia tinctorium L.) } & Alum of aluminium & \multirow{5}{*}{3} & 4 & $3 / 4$ \\
\hline & Ferro sulphate & & 7 & $4 / 5$ \\
\hline & Coppersulphate & & 8 & $4 / 5$ \\
\hline & Potassium-bichromate & & 7 & 4 \\
\hline & Sodium- chloride & & 6 & 4 \\
\hline & Alum of aluminium+ Ferro sulphate & \multirow{11}{*}{$1.5+1.5$} & 5 & $4 / 5$ \\
\hline & Alum of aluminium + Coppersulphate & & 5 & $4 / 5$ \\
\hline & Alum of aluminium + Potassium-bichromate & & 4 & $4 / 5$ \\
\hline & Alum of aluminium + Sodium- chloride & & 5 & $4 / 5$ \\
\hline & Ferrosulphate + Coppersulphate & & 5 & 4 \\
\hline & Ferrosulphate+ Potassium-bichromate & & 5 & 4 \\
\hline & Ferrosulphate + Sodium- chloride & & 5 & 4 \\
\hline & Coppersulphate + Potassium-bichromate & & 5 & $4 / 5$ \\
\hline & Coppersulphate + Sodium- chloride & & 4 & 4 \\
\hline & Potassiumbichromate + Sodium- chloride & & 5 & $4 / 5$ \\
\hline & Without mordant & & 5 & 4 \\
\hline \multirow{16}{*}{$\begin{array}{l}\text { Camomile } \\
\text { (Anthemis tinctoria L.) }\end{array}$} & Alum of aluminium & \multirow{5}{*}{3} & 5 & $4 / 5$ \\
\hline & Ferro sulphate & & 7 & 4 \\
\hline & Coppersulphate & & 7 & $3 / 4$ \\
\hline & Potassium-bichromate & & 6 & $4 / 5$ \\
\hline & Sodium- chloride & & 4 & 5 \\
\hline & Alum of aluminium+ Ferro sulphate & \multirow{11}{*}{$1.5+1.5$} & 5 & 4 \\
\hline & Alum of aluminium + Coppersulphate & & 6 & $4 / 5$ \\
\hline & Alum of aluminium + Potassium-bichromate & & 5 & $4 / 5$ \\
\hline & Alum of aluminium + Sodium- chloride & & 4 & 5 \\
\hline & Ferrosulphate + Coppersulphate & & 7 & 4 \\
\hline & Ferrosulphate+ Potassium-bichromate & & 5 & $4 / 5$ \\
\hline & Ferrosulphate + Sodium- chloride & & 5 & $4 / 5$ \\
\hline & Coppersulphate + Potassium-bichromate & & 6 & $4 / 5$ \\
\hline & Coppersulphate+ Sodium- chloride & & 5 & 4 \\
\hline & Potassiumbichromate + Sodium- chloride & & 5 & 5 \\
\hline & Without mordant & & 4 & $4 / 5$ \\
\hline
\end{tabular}

When Table 3 is examined, it is seen that colours 'obtained by mordant and without mordant methods from sage, light fastness values are between 5-8. Dyeing with sodiumchloride, alum of aluminium+ potassium-bichromate and coppersulphate + sodium-chloride mordants gave minimum value as 5; ferro-sulphate and ferro-sulphate+ potassiumbichromate mordants gave maximum value as 8 . Abrasion fastness values are between 3/4-5. Dyeing made by without mordant gave maximum value as 5, coppersulphate+ potassium-bichromate mordants dyeing gave minimum value as $3 / 4$.

Light fastness values obtained from safflower by using mordant and without mordant methods change between 4-6. Dyeing with coppersulphate, potassium-bichromate, sodium- chloride, potassium-bichromate+ sodium-chloride and without mordants gave minimum value as 4; ferro-sulphate, alum of aluminium + ferro sulphate, alum of aluminium + coppersulphate and ferro-sulphate + coppersulphate mordants gave maximum value as 6 . Abrasion fastness values change between 3/4 and 5. Dyeing made by alum of aluminium and potassium-bichromate mordants gave maximum value as 5 , ferrosulphate + potassium-bichromate mordants dyeing gave minimum value as $3 / 4$.

Light fastness values obtained from walnut by using mordant and without mordant methods change between 6-8. Dyeing made by coppersulphate, sodium-chloride and alum of aluminium + coppersulphate gave minimum value as 6 ; alum of aluminium, ferro-sulfate, potassium-bichromate, 
alum of aluminium + ferro sulphate, alum of aluminium + sodium-chloride, ferrosulphate + coppersulphate and ferrosulphate + sodium-cloride gave maximum value as 8 . Abrasion fastness values change between 2 and 4/5. Dyeing made by without mordant gave maximum value as $4 / 5$ and coppersulphate mordant gave minimum value as 2 .

Light fastness values obtained from madder by using mordant and without mordant methods change between 4-8. Alum of aluminium, alum of aluminium+ potassiumbichromate and copper-sulphate+ sodium-chloride mordants gave minimum value as 4 ; coppersulphate mordant gave maximum value as 8 . Abrasion fastness values change between $3 / 4$ and $4 / 5$. Alum of aluminium mordant gave minimum value as $3 / 4$, and ferro sulphate, coppersulphate, alum of aluminium + ferro sulphate, alum of aluminium+ coppersulphate, alum of aluminium + potassium-bicromate, alum of aluminium + sodium-chloride, coppersulphate+ potassium-bichromate and potassium-bichromate+ sodiumchloride mordants gave maximum value as $4 / 5$.

Light fastness values obtained from camomile plant by using mordant and without mordant methods change between 4-7. Sodium-chloride, alum of aluminium+ sodium-chloride mordant and dyeing without mordant gave minimum value as 4; ferro sulphate, coppersulphate and ferrosulphate+ coppersulphate mordants gave maximum value as 7 . Abrasion fastness values change between $3 / 4$ and 5 . Coppersulphate mordant gave minimum value as $3 / 4$, and sodium-chloride, alum of aluminium + sodium-chloride and potassiumbichromate + sodium-chloride mordants gave maximum value as 5 .

In this research, colours obtained from sage, safflower, walnut, madder and camomile plants were compared with the researches about this subject. However, while there are no enough experiments about this subject light and abrasion fastness of those colours were not discussed.

Finally, if colours obtained from plants used for this research and fastness values of those colours are considered, those plants for hand weaved carpets and rugs is appropriate.

\section{References}

[1] Anonymous, 1970. DIN 5033 (Farbmessung Begriffe der Farbmetrik ), Germany.

[2] Anonymous, 1978. Colour Fastness Experiment Methods for Dyed or Pressed Textiles Determination of Colour Fastness According to Abrasion, Public of TSE, TS 717, Ankara.

[3] Anonymous, 1984 a. Colour Fastness Experiment Methods for Dyed or Pressed Textiles Determination of Colour Fastness According to Sunlight, Public of TSE, TS 867, Ankara.

[4] Anonymous, 1984 b. Methods of the Using of the Gray Scale for Sum Up the Staining (Leaking of Dye) and Discolouring (Changing of Colour) for the Determination of Colour Fastness Values of Textiles, Public of TSE, TS 423, Ankara.

[5] Anonymous, 2000. Sodexim 1866 Tristimulus Colourimeter Usage Guide.

[6] Arlı, M, Kayabaşı, N., Şanlı, H.S., Etikan, S., 2003. A Research About Determination of Colours, by Using Calorimeter, Obtained from Some Plants Used for Plant Dyeing in Turkey, University of Ankara Home Economics Graduates Foundation Publications, Science Serial: 4, University of Ankara Press, Ankara.

[7] Harmancioğlu, M., 1955. Fastness Levels, on Wool Against Various Effects, of Colours Obtained From Important Plant Dyes in Turkey. University of Ankara, Agriculture Faculty Press. Number: 77, University of Ankara Press, Ankara.

[8] Kayabaşı, N., Şanlı, H.S., Etikan, S., 2003. Evaluation of Colours Obtained by Different Mordanting Methods from Some Plants with Objective Method. 7.Türk-Alman Tarımsal Araştırma Sonuçları Sempozyumu. 79-86, Ankara.

[9] Kayabaş1, N., Başalma, D., Şanlı, H.S., 2012. Colours Obtained from Safflower (Carthamus tinctorius L.) Types and Their Fastness Values. Asian Journal of Chemistry Journals, Vol.24, No.5: 2003-2006.

[10] Şanl1, H.S., Kayabaşı, N., Ölmez, F.N, 2011. Dyeing Techniques and Mordanting Methods Applied in Natural Dyeing of Wool in Turkey. Asian Journal of Chemistry Journals, Vol.23, No.8: 3313-3316. 